\title{
Formation Pattern State Defense Reserve Components in Five Countries of Asean
}

\section{Bayu Setiawan}

\author{
Student of Doctoral Programme of Management Science of Human Resource \\ Post-Graduate Programme of Jakarta State University \\ email: sribayuprifafi@yahoo.co.id
}

\begin{abstract}
This research is a qualitative research, which aims to describe the ideal pattern for Indonesia in building the reserve component base on the result of benchmarking and review of the formation pattern of the Asean countries, namely Indonesia, Malaysia, Singapore, the Phlilipines, and Thailand. The place of research were Directorate of Reserve Component and the Directorate of State Defense of Defense Potential, Directorate General of Defense Potential, Ministry of Defence of the Republic of Indonesia, Commission I of the House of Representatives, and the Defence Attache of the five Asean countries. The data was collected by using Focus Group Discussion method, questionnaires, interviews, direct observation, and document verification. Data analysis was perfomed using a model of the Analytical Hierarchy Process (AHP) Thomas L. Saaty, such as, to determine actor, pattern, and actor with the highest priority and become the most important criteria in the formation of national defense reserve component in five Asian countries. Result of research on the highest priority and the most important criteria: (1) for Factor: Deterrent Power; (2) for Pattern: Budgeting; and (3) for Actor: the Thailand Kingdom. In this study we analyzed the implementation of eight key competences of Michael Zwell, ie, beliefs and values, skills, experience, personality traits, motivation, control emotional issues, intellectual ability, and the culture of the organization in six patterns for the formation of national defense reserve component in the Kingdom of Thailand, namely recruitment, training (development), use (utilities), closure, reward and punishment, and budgeting. The result of the analysis shows that the model and the development time in military basic training phase has the highest priority in improving the competence of members of the reserve component. In order to increase the deterrent power of the nation and country, Indonesia needs the competence of members of the reserve components that are national resources defense. Therefore, to improve the competence of defense reserve component member of the country, Indonesia needs to implement eight key competences of Michael Zwell into the military basic training curriculum, which is the part of a national programme to defend the country, and put the Ministry of Defence as a leading sector.
\end{abstract}

Keywords: factor, pattern, actor, training, detterent, competence.

\section{Introduction}

The development of a state defense system that is responsive against change of threat needs preparedness of all elements of a nation to move together efficiently and effectively. An efficient and effective system integrates all the superiority intrinsic values of the indonesianism cultural patriotism with a constellation of geo-political and geo-strategy with archipelago characteristic which one form of implementation is establishment of national defense reserve component.

Empirically, reserve components have established in many countries, either through application of conscription system or voluntarily, and several countries oblige their citizens, especially youth, to join conscription, show form of power and ability to defend the country as well high nationalism to their citizens. The experience of several countries in establishing state defense reserve components can be precious lesson and more strengthens Indonesia to establish its state defense reserve components.

Through this research, the researcher made benchmarking to the experience of five ASEAN countries, namely Indonesia, Malaysia, Singapore, Philippines, and Thailand in establishment of defense reserve components in the respective country, namely recruitment pattern, mentoring pattern, usage pattern, termination pattern, reward and punishment pattern, and budgeting pattern 


\section{Purpose}

This research aims to determine factors, patterns, and actors with the highest priority and become the most important criteria in establishment of state defense reserve component in five ASEAN countries, namely Indonesia, Malaysia, Singapura, Philippines, and Thailand by using Analytical Hierarchi Process(AHP) model of Thomas L. Saaty; and study the application of eight competence factors of Michael Zwell to actors with the highest priority and become the most important criteria in establishment of state defense reserve component in five Asean countries, in order to determine the pattern most accomodate the interest of competence improvement to realize the deterrence in the field of state defense.

\section{Research Methods}

This research uses qualitative approach focusing on the existing symptoms and patterns in the subjects being studied, and the researcher was involved in carrying out data investment and in developing interpretation on the data found. As for the method used in this research is analytic descriptive based on literature study and observation which focus on the aspect of experience on the establishment pattern of national defense reserve component in five Asean countries, namely Indonesia, Malaysia, Singapore, Philippines, and Thailand.

\section{Result and Discussion}

Based on the answer upon 309 questions in the form of questionnaires which given to the approximately 30 respondents (experts in defense) participant of Focus Group DiscussionInformation Sharing of Reserve Componentin the five Asean countries as referred to above, 12,760 answers, which results then tabulated for data analysis material by using the approach of Analytical Hierarchie Process (AHP).

The main goal of this hierarchy, firstly, to choose Priority Factor of 3 (three) Factors become strategy foundation of establishment of National defense reserve component, namely Strength Factor, Ability Factor, as well as State and Nation Deterrence Factor; secondly, is to choose Priority pattern from 6 (six) Component Establishment Patterns, namely Recruitment Pattern, Mentoring Pattern, Usage Pattern, Termination Pattern, Reward and Punishment Pattern, and Budgeting Pattern; and third, is to choose Priority of 5 (five) Asean country actors, namely Indonesia, Malaysia, Singapore, Philippines, and Thailand.

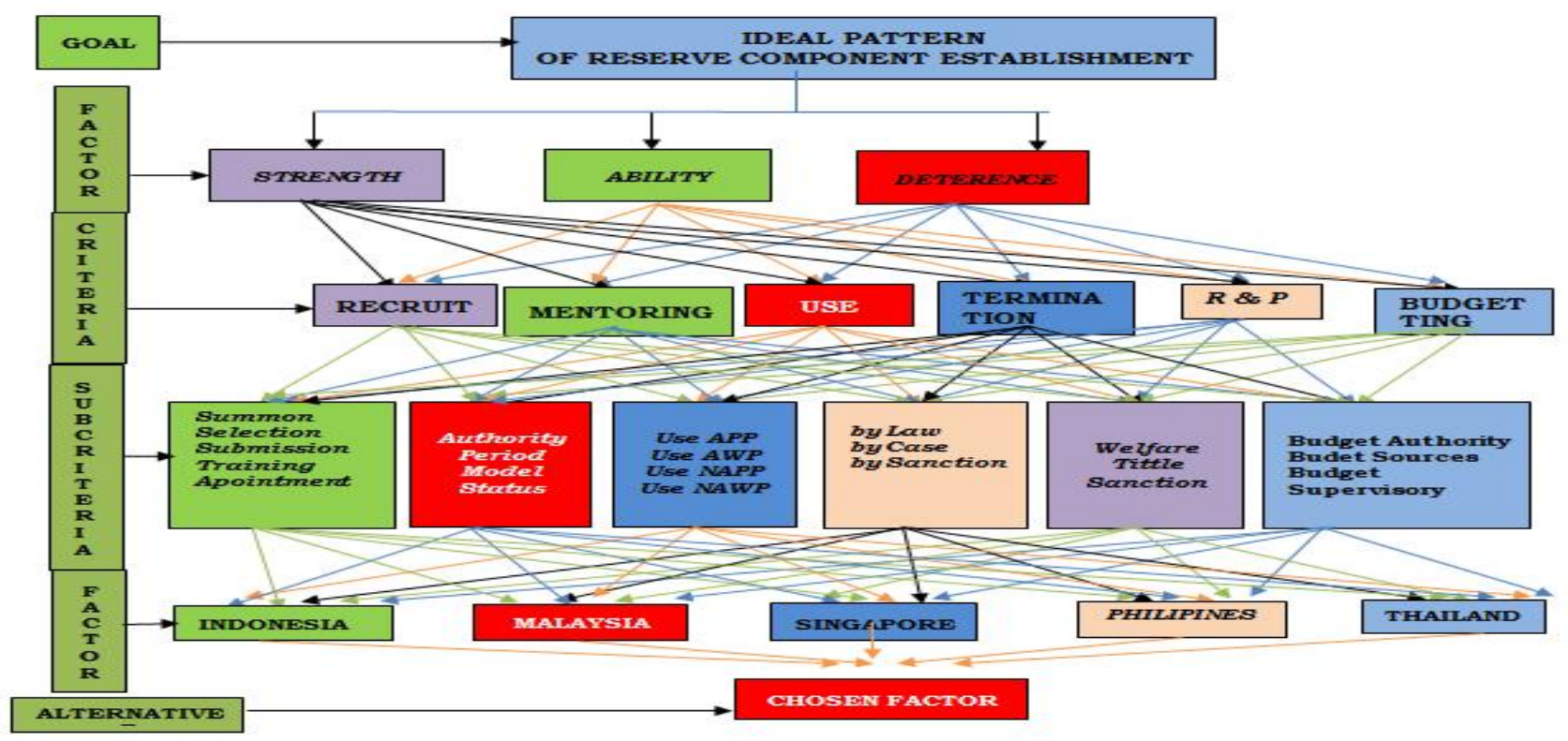

Figure 1. Hierarchy Structure of Matrix Theory 
The calculation of matrix theory by using Thomas L. Saaty's AHP Approach upon data of questionnaire answer tabulation result as described above resulted the priorities as follows:

Priority benchmarking result in First Level Hierarchy Element (Factor) consisting of: Strength Factor, Ability Factor, as well as State and Nation Deterrence Factor, is as follows: Power (0.7148), Ability (0.9949), and Deterrence $(1,2891)$. Benchmarking result with calculation based on such matrix theory shows that Deterrence Factor is an element with the highest priority and becomes the most important criteria in establishment of national defense reserve component, followed by Ability Factor, and Strength Factor.

Priority benchmarking result in Second Level Hierarchy Element Level (Criteria) consisting of: Recruitment Pattern, Mentoring Pattern, Usage Pattern, Termination Pattern, Reward and Punishment Pattern, and Budgetting Pattern, is as follows: Recruitmen $(0,1007)$, Mentoring (0.1270), Usage (0.1451), Termination (0.1646), Reward and Punishment(0.2088), and Budgeting (0.2533). Priority benchmarking result based on such matrix theory, shows that Budgeting Pattern in an element with the highest priority and becomes the most important criteria in choosing pattern in establishment of national defense reserve component, followed by Reward and Punishment Pattern, Termination, Usage, Mentoring and Recruitment Pattern.

Priority benchmarking result in Third Level Hierarchy Element Level (Actor) consisting of: Indonesia, Malaysia, Singapore, Philippines, and Thailand, is as follows: Indonesia (0.1345), Malaysia (0.1676), Singapore (0.2188), Philippines (0.2382), and Thailand (0.3303).

The result of priority benchmarking based on the calculation of such matrix theory shows that Thailand is the Actor with the highest priority and becomes the most important criteria in establishment of national defense reserve component, followed by Philippines, Singapore, Malaysia, and Indonesia.

As for the priority comparison result in Sub-Criteria Hierarchy Level, consisting of 22 Subcriterias, with the AHP approach of Michael Saaty can be explained in the Table 1:

Research result upon all data collected in FGD (Forum Group Discussion), Questionnaire, Interview, Observation, and Document Study is as follows:

Deterrence is an element with the highest priority and becomes the most important criteria;

Budgeting pattern is an element with the highest priority and becomes the most important criteria;

Thailand Kingdom is an Actor with the highest priority and becomes the most important criteria; and

Model and time of mentoring in the phase of military basic training must be considered through competence improvement of participants of national defense reserve component training of Indonesia version.

\section{Discussion}

The calculation result of Thomas L. Saaty' AHP matrix theory shows that deterrence is worth to be considered as reference for Indonesia in embodying qualified defense resource through establishment of its reserve component. State deterrence in defending itself against wide range of threats highly depends on the quality of defense human resource ability owned. The ability quality of defense human resources can be improved through application of competence factors.

Michael Zwell conveys there are 8 (eight) factors that can influence a person's competence proficiency, namely belief and values, skill, experience, personality characteristic, motivation, emotional issue control, intellectual ability, and organization culture. Analysis on the application of those eight competence factors of Michael Zwell to six patterns of establishment of national defense reserve component to determine the pattern most accommodates the competence improvement interest in order to realize deterrence in the field of defense,can be explained as follows (Figure 2): 
Table 1. The Priority Comparison Result in Sub-Criteria Hierarchy Level

\begin{tabular}{|c|c|c|c|c|c|}
\hline & Indonesia & Malaysia & Singapore & Philippines & Thailand \\
\hline Summon & 0.1345 & 0.1676 & 0.2188 & 0.2382 & 0.3303 \\
\hline Selection & 0.1236 & 0.1583 & 0.1899 & 0.2194 & 0.3085 \\
\hline Submission & 0.1213 & 0.1568 & 0.1928 & 0.2249 & 0.3039 \\
\hline Training & 0.1158 & 1.1597 & 0.1683 & 0.2295 & 0.2958 \\
\hline Appointment & 0.1238 & 0.1543 & 0.1972 & 0.2249 & 0.2996 \\
\hline Authority & 0.1230 & 0.1518 & 0.1975 & 0.2275 & 0.2999 \\
\hline Mentoring Period & 0.1248 & 0.1518 & 0.1951 & 0.2263 & 0.2983 \\
\hline Mentoring Model & 0.1148 & 0.1516 & 0.1984 & 0.2294 & 0.3051 \\
\hline Mentoring Status & 0.1173 & 0.1421 & 0.1839 & 0.2332 & 0.3234 \\
\hline Use of APP & 0.1201 & 0.1542 & 0.1969 & 0.2318 & 0.2967 \\
\hline Use of AWP & 0.1248 & 0.1549 & 0.1934 & 0.2309 & 0.2951 \\
\hline Use of NAPP & 0.1155 & 0.1518 & 0.1994 & 0.2346 & 0.2986 \\
\hline Use of NAWP & 0.1253 & 0.1529 & 0.1974 & 0.2730 & 0.2986 \\
\hline Termination by Law & 0.1159 & 0.1523 & 0.1868 & 0.2429 & 0.3017 \\
\hline Termination by Case & 0.1090 & 0.1408 & 0.1869 & 0.2564 & 0.3006 \\
\hline Termination by Sanction & 0.1148 & 0.1472 & 0.1825 & 0.2372 & 0.3179 \\
\hline Welfare Reward & 0.1089 & 0.1534 & 0.2099 & 0.2308 & 0.2987 \\
\hline Title Reward & 0.1147 & 0.1533 & 0.1965 & 0.2292 & 0.3041 \\
\hline Punishment as Sanction & 0.1107 & 0.1400 & 0.1792 & 0.2441 & 0.3258 \\
\hline Budgetting Authority & 0.1090 & 0.1445 & 0.1900 & 0.2425 & 0.3139 \\
\hline Budgetting Sources & 0.1216 & 0.1487 & 0.1917 & 0.2363 & 0.3015 \\
\hline Budgetting Supervisory & 0.1170 & 0.1416 & 0.1850 & 0.2410 & 0.3124 \\
\hline
\end{tabular}

To determine the priority level of competence factors to the patterns used in establishment of national defense reserve component in Thailand Kingdom, the researcher gave weighting in the form of score on existence level of each competence factors within the referred patterns.

Based on calculation of the total score will be obtained a pattern most accommodates the application of competence factors in the establishment of national defense reserve component in Thailand Kingdom. The referred pattern can be considered as an input to arrange alternative pattern for Indonesia in establishing its reserve component.

The Implementation of the competence patterns priority level in the framework of establishment of national defense reserve component in Thailand Kingdom is based on calculation result by summing up the score value of each factor and patterns having been determined, with score weighting as follows:

$1=$ Competence Factor Very Less Accomodated in Pattern.

3 = Competence Factor Less Accomodated in Pattern.

$5=$ Competence Factor Sufficiently Accomodated in Pattern.

7 = Competence Factor Accomodated in Pattern.

9 = Competence Factor Significantly Accomodated in Pattern. 


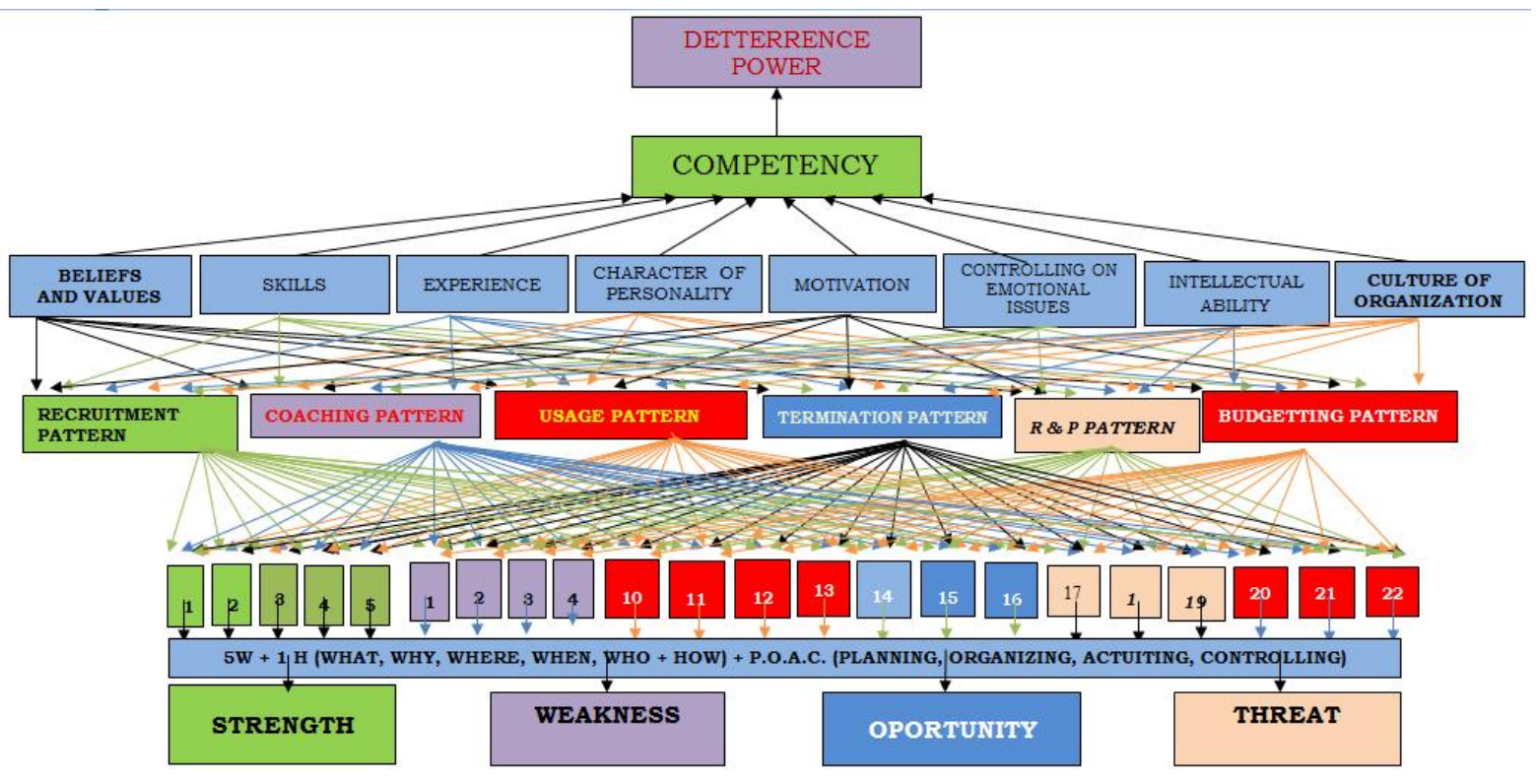

Figure 2. The matrix of the Michael Zwell's Eight Competency Factors Implementationon Actor with high Priority

In the above description is has explained that Thailand Kingdom applies six patterns in the establishment of its national defense reserve component, namely: recruitment pattern, mentoring pattern, usage pattern, termination pattern, reward and punishment pattern, and budgeting pattern.

In the meantime, Michael Zwell conveyed that there are 8 Competence Factors that can affect a person's competence proficieny, namely belief and values, skill, experience, personality characteristic, motivation, emotional issue control, intellectual ability, and organization culture.

Therefore, analysis on the application of 8 (eight) Competence Factors to 6 (six) Patterns of Establishment of National Defense Reserve component, include application of 8 (eight) Competence Factors to Recruitment Pattern, Mentoring Pattern, Usage Pattern, Termination Patern, Reward and Punishment Pattern, and Budgeting Pattern.

Table 2. The Implementation of the Eight Compentency factors on the Recruitment Pattern of the Contacting Phase

\begin{tabular}{|c|l|c|c|}
\hline No & Competency Factors & Recruitment Factors & Score Value \\
\hline 1 & Beliefs and Values & Contacting Phase & 3 \\
\hline 2 & Skills & Contacting Phase & 3 \\
\hline 3 & Experience & Contacting Phase & 3 \\
\hline 4 & Character of Personality & Contacting Phase & 3 \\
\hline 5 & Motivation & Contacting Phase & 3 \\
\hline 6 & Emotional Issues & Contacting Phase & 3 \\
\hline 7 & Intellectual Complexy & Contacting Phase & 3 \\
\hline 8 & Culture of Organization & Contacting Phase & 3 \\
\hline \multicolumn{2}{|c|}{ TOTAL } & $\mathbf{2 4}$ \\
\hline
\end{tabular}

To know whether the competence factors are accommodated in the patterns in question, in this article, the researcher presents example on application of 8 (eight) Competence Factors to 
Recruitment Pattern which includes five stages, namely summon stage, selection stage, submission stage, training stage, and appointment stage.

The Implementation of the 8 Competence Factors, namely belief and values, skill, experience, personality characteristic, motivation, emotional issue control, intellectual ability, and organization culture, in summon stage, selection stage, submission stage, training stage, and appointment stage, can be described in Table 2:

According to Michael Zwell, beliefs and values defined as a person's beliefs and values on $\mathrm{him} /$ herself and on others which will significantly influence her or his behavior. If a person believes that he is not creative and innovative, he will not seek to think about a new or different method in doing something. Therefore, every person must think positively about himself, and to others and shows the characteristic of a person who thinks forward.

Summon is one stage of recruitment pattern in the framework of establishment of its national defense reserve component in Thailand Kingdom applied by Ministry of Defense of Thailand Kingdom, supported by the elements of army, institution and all related parties.

Based on Michael Zwell's opinion as referred to above, there is chance in the summon procedure to embed beliefs and values to the candidate members of the relevant reserve component in the defending the country through participation as reserve component members.

In the perspective of national defense, the efforts to embed belief and value is a strength and opportunity at the same time for the reserve component members to have competence so can be more professional in carrying out their duties. The embedding of belief and value to Thailand citizens is applied when a person is stated to be selected to participate in training program as reserve component member candidate, and it is responded by society by giving high aspiration, so that the relevant reserve component member candidate perceives pride accordingly.

The officers who involve in the recruitment committee have obtained great trust from the state to be able to carry out the duties which indirectly implied to the belief and value embedding, even though technically it is done through lottery. Those who selected as the national defense reserve component member candidates in Thailand Kingdom, in addition obtain recognition as the best candidates who have complied with the requirement are also trusted to have blessing and better fortune than other candidates.

However, the effort to embed "belief and value" in summon stage is not explicitly accommodated in summon state which constitutes one part of recruitment pattern in the framework of establishment of its national defense reserve component in Thailand Kingdom.

Consequently, "belief and value" as one of the factors that can affect a person's competence proficiency, is considered less accomodated in summon stage in recruitment pattern in the framework of establishment of national defense reserve component in Thailand Kingdom.

Based on the priority of competence factors interest over the patterns applied in the framework of establishment of its national defense reserve component in Thailand Kingdom, score weighting for "belief and value" accomocation insummon stage in recruitment pattern is 3 .

The Synthesis on the analysis report on application of 8 (eight) factors that can affect a person's competence proficiency, in six patterns in the establishment of state defense reserve component in Thailand Kingdom, can be explained in the following table 3:

Synthesis matrix on application of competence factor to the establishment pattern of national defense reserve component in Thailand Kingdom as referred to in above, shows that model and mentoring time in mentoring pattern and military basic training stage in recruitment pattern, obtained the highest value/score.

Consecutively, the average score achievement for each pattern are: mentoring model obtained value 8 (total score 64 divided by 8 competence factors); mentoring time obtained score 7 (total score 56 divided by 8 competence factors); and military basic training also obtained score 7 (total score 56 divided by 8 competence factors). This implies that based on calculation result on application of competence factors to the establishment the patterns of national defense reserve component in Thailand Kingdom, obtained result that priority of factors interest level which can affect a person's competence proficiency can only accommodate to patterns, namely recruitment pattern in military basic training state and mentoring pattern in mentoring model and mentoring time. 
Table 3. The Analysis Report on Application of 8 (Eight) Factors That Can Affect A Person's Competence Proficiency

\begin{tabular}{|c|c|c|c|c|c|}
\hline $\mathrm{NO}$ & Competence Factors & Pattern & Score & Number & Desc \\
\hline 1 & $\begin{array}{ll}\text { a. } & \text { Beliefs and Values } \\
\text { b. } & \text { Skills } \\
\text { c. } & \text { Experience } \\
\text { d. } & \text { Personality Characteristic } \\
\text { e. } & \text { Motivation } \\
\text { f. } & \text { Emotional Issue } \\
\text { g. } & \text { Intellectual Ability } \\
\text { h. } & \text { Organization Culture }\end{array}$ & $\begin{array}{l}\text { Recruitment } \\
\text { Summon } \\
\text { Selection } \\
\text { Briefing } \\
\text { Military Training } \\
\text { Appointment }\end{array}$ & $\begin{array}{l}3+3+3+3+3+3+3+3 \\
3+3+3+3+3+3+3+3 \\
3+3+3+3+3+3+3+3 \\
7+9+5+7+9+5+7+7 \\
3+3+3+3+3+3+3+3\end{array}$ & $\begin{array}{l}24 \\
24 \\
24 \\
56 \\
24\end{array}$ & Prior \\
\hline 2 & $\begin{array}{ll}\text { a. } & \text { Beliefs and Values } \\
\text { b. } & \text { Skills } \\
\text { c. } & \text { Experience } \\
\text { d. } & \text { Personality Characteristic } \\
\text { e. } & \text { Motivation } \\
\text { f. } & \text { Emotional Issue } \\
\text { g. } & \text { Intellectual Ability } \\
\text { h. } & \text { Organization Culture }\end{array}$ & $\begin{array}{l}\text { Mentoring } \\
\text { Authority } \\
\text { Time } \\
\text { Model } \\
\text { Status }\end{array}$ & $\begin{array}{l}3+3+3+3+3+3+3+3 \\
7+7+7+7+7+7+7+7 \\
9+9+7+9+9+7+7+7 \\
3+3+3+3+3+3+3+3\end{array}$ & $\begin{array}{l}24 \\
56 \\
64 \\
24\end{array}$ & $\begin{array}{l}\text { Prior } \\
\text { Prior }\end{array}$ \\
\hline 3 & $\begin{array}{ll}\text { a. } & \text { Beliefs and Values } \\
\text { b. } & \text { Skills } \\
\text { c. } & \text { Experience } \\
\text { d. } & \text { Personality Characteristic } \\
\text { e. } & \text { Motivation } \\
\text { f. } & \text { Emotional Issue } \\
\text { g. } & \text { Intellectual Ability } \\
\text { h. } & \text { Organization Culture } \\
\end{array}$ & $\begin{array}{l}\text { Use } \\
\text { APP } \\
\text { AWP } \\
\text { NAPP } \\
\text { NAWP }\end{array}$ & $\begin{array}{l}3+3+3+3+3+3+3+3 \\
3+3+3+3+3+3+3+3 \\
3+3+3+3+3+3+3+3 \\
3+3+3+3+3+3+3+3\end{array}$ & $\begin{array}{l}24 \\
24 \\
24 \\
24\end{array}$ & \\
\hline 4 & $\begin{array}{ll}\text { a. } & \text { Beliefs and Values } \\
\text { b. } & \text { Skills } \\
\text { c. } & \text { Experience } \\
\text { d. } & \text { Personality Characteristic } \\
\text { e. } & \text { Motivation } \\
\text { f. } & \text { Emotional Issue } \\
\text { g. } & \text { Intellectual Ability } \\
\text { h. } & \text { Organization Culture } \\
\end{array}$ & $\begin{array}{l}\text { Termination } \\
\text { by Law } \\
\text { by Case } \\
\text { by Sanction }\end{array}$ & $\begin{array}{l}3+3+3+3+3+3+3+3 \\
3+3+3+3+3+3+3+3 \\
3+3+3+3+3+3+3+3\end{array}$ & $\begin{array}{l}24 \\
24 \\
24\end{array}$ & \\
\hline 5 & $\begin{array}{ll}\text { a. } & \text { Beliefs and Values } \\
\text { b. } & \text { Skills } \\
\text { c. } & \text { Experience } \\
\text { d. } & \text { Personality Characteristic } \\
\text { e. } & \text { Motivation } \\
\text { f. } & \text { Emotional Issue } \\
\text { g. } & \text { Intellectual Ability } \\
\text { h. } & \text { Organization Culture }\end{array}$ & $\begin{array}{l}\text { Reward and Punishment } \\
\text { Welfare } \\
\text { Title } \\
\text { Punishment }\end{array}$ & $\begin{array}{l}3+3+3+3+3+3+3+3 \\
3+3+3+3+3+3+3+3 \\
3+3+3+3+3+3+3+3\end{array}$ & $\begin{array}{l}24 \\
24 \\
24\end{array}$ & \\
\hline 6 & $\begin{array}{ll}\text { a. } & \text { Beliefs and Values } \\
\text { b. } & \text { Skills } \\
\text { c. } & \text { Experience } \\
\text { d. } & \text { Personality Characteristic } \\
\text { e. } & \text { Motivation } \\
\text { f. } & \text { Emotional Issue } \\
\text { g. } & \text { Intellectual Ability } \\
\text { h. } & \text { Organization Culture }\end{array}$ & $\begin{array}{l}\text { Budgeting } \\
\text { Authority } \\
\text { Sources } \\
\text { Supervisory }\end{array}$ & $\begin{array}{l}3+3+3+3+3+3+3+3 \\
3+3+3+3+3+3+3+3 \\
3+3+3+3+3+3+3+3\end{array}$ & $\begin{array}{l}24 \\
24 \\
24\end{array}$ & \\
\hline
\end{tabular}

Thus, experience of Thailand Kingdom in establishing its defense reserve component, can be the consideration for Indonesia in establishing its defense reserve component in order to have high 
competence and professional so that can be expected to be able to increase the state and nation deterrence against all kinds of threats.

Therefore, to establish nation defense reserve component that has high competence and deterrencebased professional, it requires programme and activity that can seek accomocation of the interest of competence factors in military basic training stage, supporting by mentoring model and mentoring time, in an establishment mechanism of national defense reserve component which is carried according to management cycle covering the stage of planning, organizing, implementing and supervising.

In order to establish Indonesian human resources as national asset of defense become an ideal military deterrence which is not based on to fulfillment of the main equipments of weapon system, it needs competency improvement effort that is contained into the activities of military basic training, mentoring model, and mentoring time in the framework of establishment of national defense reserve component in Indonesia.

Alternative of application of competence factor in training model for candidate member of state defense reserve components and state defense cadre can be explained in the following Table 4:

Table 4. Competence Factor in Training Model for Candidate Member of State Defense Reserve Components and State Defense Cadre

\begin{tabular}{|c|c|c|c|}
\hline Material & $\begin{array}{l}\text { Competency } \\
\text { Factors }\end{array}$ & Model & Curriculum \\
\hline $\begin{array}{l}\text { Candidate Member: } \\
\text { awareness, on citizen's right and } \\
\text { obligation } \\
\text { confidence in self-strength } \\
\text { mutual cooperation } \\
\text { never give up } \\
\text { ability to cooperate } \\
\text { integrity } \\
\text { totality } \\
\text { togetherness } \\
\text { State Defend Cadre: } \\
\text { mental attitude nd state defend } \\
\text { character } \\
\text { national and state patriotism } \\
\text { anda awareness } \\
\text { loyal to Pancasila as the } \\
\text { ideology } \\
\text { willing to scrifice for nation and } \\
\text { state } \\
\text { initial capability to defend state } \\
\text { both psychologically and } \\
\text { physically }\end{array}$ & $\begin{array}{l}\text { Believe and Value } \\
\text { Skill } \\
\text { Experience } \\
\text { Personality } \\
\text { Characteristic } \\
\text { Motivation } \\
\text { Pengendalian } \\
\text { Emotional Issue } \\
\text { Intellectual Ability } \\
\text { Organization } \\
\text { Culture }\end{array}$ & $\begin{array}{l}\text { Education } \\
\text { Mentoring } \\
\text { Training } \\
\text { Coaching: } \\
\text { Observation } \\
\text { Discussion } \\
\text { Aktif } \\
\text { Follow Up } \\
\text { Mentoring } \\
\text { Initiation } \\
\text { Cultivation } \\
\text { Sepearation } \\
\text { Redefinition } \\
\text { Counselling } \\
\text { Recognition } \\
\text { Empowering } \\
\text { Resourcing }\end{array}$ & $\begin{array}{l}\text { Personality mentoring } \\
\text { and fighting spirit: } \\
\text { Mentoring of } \\
\text { knowledge and skill } \\
\text { Field Study } \\
\text { Basic } \\
\text { Core } \\
\text { Supporting } \\
\text { Skill }\end{array}$ \\
\hline
\end{tabular}

\section{Conclusions}

Based on the approach of the AHP matrix theory of Thomas L. Saaty, in this theory has been able to be determined factor, pattern and actor with the highest priority and become the most important criteria in the establishment of state defense reserve components in 5 Asean countries, respectively are Deterrence Factor, Budgeting Pattern, and Thailand Kingdom Actor.

Analysis on the implementation of eight competence factors of Michael Zwell to the actor with the highest priority and become the most important criteria in the establishment of state defense 
reserve components in 5 Asean countries generated research finding that training is a the most accommodating sub-pattern the interest of competence improvement to realize deterrence in the field of state defense.

In order to improve the competency of Indonesian citizens who participate in defending state either as members of state defense reserve component or as state defense cadre, so as to have deterrence towards wide range of threats, it needs curriculum of training implementation that accommodates 8 (eight) Competence Factors of Michael Zwell.

\section{Bibliography}

Colquit, Jason A., Jeffery A. LePine and Michael J. Wesson. Organizational Behavior Improving Performance and Commitment it the Workplace, International Edition.New York: McGraw-Hill Companies Inc., 2009.

Dessler,Gary. Human Resource Management, Thirteenth Edition. London: Pearson Education, Inc., 2013.

Ivancevich, John M., Robert Konopaske and Michael T. Matteson. Organizational Behavior and Management, Eighth Edition. New York: McGraw-Hill Companies Inc., 2008.

Mondy, R. Wayne, Robert M. Noe and Shane R. Premeaux.Human Resource Management, 7th Edition. New Jersey: Prentice Hall, 2000.

Noe,Raymond A., John R. Hollenbeck, Barry Gerhart and Patrick M. Wright. Fundamental of Human Resource Management, Fourth Edition. New York: McGraw-Hill Companies Inc., 2011.

Robbins, Stephen P. Organizational Behavior, Tenth Edition. New Jersey: Prentice Hall, 2003.

Wibowo. Manajemen Kinerja, Edisi Ketiga. Jakarta: PT RajaGrafindo Persada, 2007.

Zwell, Michael. Creating a Culture of Competence, New York: John Wiley \& Sons, Inc., 2000. 